\title{
МІСЦЕ КАТЕГОРІЇ «ЦІННІСТЬ» У ТЕОРІЇ ПРАВОВОЇ КУЛЬТУРИ
}

\author{
Качур В. О., Протосавіцька Л. С.
}

\section{ВСТУП}

Сучасний розвиток суспільства відбувається під впливом глобалізації, яка охопила всі сфери суспільного життя. Успішне вирішення завдань, які постають перед світовою спільнотою та державами, залежить від цінностей, які закладені в основу їхніх правових систем. Виступаючи інструментом соціального регулювання, цінності $є$ проміжною ланкою, яка пов'язує поведінку людини 3 iі потребами, інтересами, ідеалами тощо. Цінності виконують складні і різнобічні регулятивні функції як щодо суспільства, так i щодо особистості. Тому дослідження цінностей напряму пов'язане 3 необхідністю усвідомлення національно-культурної та правової самобутності України, визначення ії місця в загальносвітовому розвитку цивілізації, з'ясування iї унікального статусу та перспектив подальшого розвитку. Вивчення цінностей вимагає всебічного аналізу їх змістовної складової частини, що опосередковується їх цивілізаційними особливостями.

Науковий інтерес до дослідження цінностей зумовлений визначальною, принциповою роллю, яку вони відіграють у людському житті. Вони засвідчують спосіб життя людини, іiї ставлення до світу, надають сенсу та цілісності світосприйняття індивіда. Крім того, вони є мірилом людського в людині й виражаються в думках, діях, усій поведінці. Тобто цінності $\epsilon$ тим, що змушує людей відчувати себе людьми.

Цінності $\epsilon$ тим, що забезпечує стабільність суспільства, основою взаєморозуміння і взаємодії людей в моменти історичних зрушень. Набувають вони особливого значення і в сучасних умовах. Науковотехнічний прогрес, індустріалізація та інформатизація усіх сфер сучасного суспільства іноді опосередковано впливають на зростання негативного ставлення до історії, культури, традицій і веде до девальвації цінностей у сучасному світі. Тому потрібен науковий аналіз не тільки наявної ціннісної ситуації, а й визначення перспектив ціннісного розвитку.

Однією з умов сталого розвитку українського суспільства $є$ правова культура, яка через цінності, що становлять іiі фундамент, дасть змогу переосмислити роль і значення державних і правових інституцій для забезпечення збереження та розвитку держави як на буденному, так i науковому рівні. 


\section{1. Через плюралізм наукових підходів розуміння поняття «цінність» до його визначення}

Проблема цінностей - це проблема, яка $є$ водночас одвічною і завжди новою. Такий незмінний інтерес до цінностей зумовлений визначальною, принциповою роллю, яку вони відіграють у людському житті. Тому формування цінностей $\epsilon$ важливим елементом людської цивілізації, оскільки для кожної людини в будь-якому куточку світу відомі та зрозумілі такі поняття, як свобода, патріотизм, громадянський обов'язок, законослухняність, любов до дітей та повага до старших, добро, зло, щастя, розпач та горе.

Питання цінностей i ïx значення, оцінки та ціннісного ставлення порушували в працях різного роду філософи, вчені, науковці (Мо-Цзи, Сократ і Платон, К. Гільвецій, І. Бентам, Д.С. Міль, Т. Гоббс, І. Кант, Г. Гегель, Є.М. Причепій, Т.В. Бутківська, С.Ш. Аваліані, С.Р. Борінштейн, А.А. Кавалеров та ін.). Кожен із дослідників звертався і звертається до різних аспектів цієї проблематики.

Вивченням теорії цінностей займається цілий науковий напрям аксіологія, який виокремився в окремий розділ філософії у другій половині XIX ст., а в науковий обіг зарубіжної філософії був уведений на початку XX ст. французьким філософом П. Лапі та німецьким філософом Н. Гартманом. Нині він охоплює вчення про природу цінностей, їх місце в реальності та структурі ціннісного світу, зв'язки цінностей між собою, із соціальними i культурними факторами, структурою особистості. Панування аксіологічних уявлень на початку XX ст. дало підстави визначити цінності центральною категорією в розумінні культури як «світу втілених цінностей» ${ }^{1}$.

Аксіологічна проблематика корінням сягає в сиву давнину, а витоки теорії цінностей варто шукати у філософських концепціях досократівського періоду. Так, представник філософської думки Стародавнього Китаю Мо-Цзи визначав найвищою цінністю справедливість, адже саме вона приносить людям користь 2 .

Історія цінностей засвідчує, що проблема цінностей у широкому розумінні розвивається саме в часи знецінення культурних традицій та деградації суспільства. У період кризи афінської демократії Сократ замислився над питанням: «Що $є$ благом?». Це питання вважається основним у загальній теорії цінностей. Античний мислитель Платон,

\footnotetext{
1 Культурологія: теорія та історія культури : Навчальний посібник / За ред. I.I. Тюрменко, О.Д. Горбула. Київ : Центр навчальної літератури, 2004. 368 c. URL: http://www.info-library.com.ua/bookstext-1114.html

${ }^{2}$ Мо-Цзы. Этические воззрения. Антология мировой философии: В 4-х т. Т. 1. Ч. 1. Москва : Мысль, 1969. C. 204.
} 
розділяючи світ на світ ідей та світ речей, вказує на більшу цінність світу ідей. Він зробив першу класифікацію цінностей (благ), розділивши їх на категорії «добре», «прекрасне», «істинне». Аристотель розробив власну класифікацію, розділивши всі блага на «цінні» (доброчесність, душа, розум), «хвалимі» (доброчесності, дії яких викликають схвалення та похвалу) та «можливі» (сила, краса, багатство, влада) ${ }^{3}$.

Таку тенденцію ми спостерігаємо і в часи середньовіччя, коли Аврелій Августин та Ф. Аквінський закцентували на християнських релігійних цінностях, і в період Відродження та Реформації. Саме тоді питання цінностей знову стало актуальним через те, що в суспільстві вкотре відбувається знецінення культурної традиції попередньої епохи. Тогочасний складний i неоднозначний процес переоцінки основ політичного життя буття зумовив утвердження нової системи соціальних і політичних цінностей. Так, англійський вчений Т. Гоббс у своєму вченні звернувся до питання народного суверенітету і природних прав людини, до яких входить право на самозбереження як одна 3 головних цінностей суспільства. Мислитель вказував, що саме з метою захисту природних прав виникла держава. Вчений розумів суспільний договір як акт конституювання держави, в процесі якого народ передає природну владу до рук держави, воля народу перетікає до рук держави, і «той, кому передано верховну владу, не зв'язаний ані законами держави, ані обов'язками перед громадянами». Його міфічний Левіафан був створений за людською подобою для іï охорони та захисту. До головних обов'язків держави Т. Гоббс зараховує забезпечення благ та безпеки народу, рівну справедливість для різних прошарків суспільства, рівномірне оподаткування, справедливе законодавство та просвітництво народу ${ }^{4}$.

Французький вчений-теоретик Ш.-Л. Монтеск'є називав цінності принципами, механізмом, що приводить у дію апарат державного управління. Він вказував на пряму залежність між цінностями, що притаманні тому чи іншому соціуму, та характером державного устрою. На його думку, такі цінності, як доброчесність та її складники (патріотизм, готовність до самопожертви, відданість загальній справі) притаманні демократії. Завдяки таким цінностям, як доброчесність та поміркованість, формується аристократія. Монархія живе за рахунок честі та честолюбства. А ось деспотія виникає, коли в суспільстві панує страх 5 .

\footnotetext{
${ }^{3}$ Кавалеров А.А. Цінність у соціокультурній трансформації. Одеса : Астропринт, 2002. С. 8-9.

${ }^{4}$ Радченко О.В. Генезис розуміння державно-управлінських цінностей у політичній філософії від нового часу до кінця ХІХ ст. Теорія і практика державного управління. Вип. 1(24) 2009. С. 2.

5 Історія вчень про право і державу: Хрестоматія для юрид. вузів і фак. / уклад., заг. ред. - проф., д-р іст. наук Г. Демиденко. 2-е вид., доп. і змін. Харків : Дух і літера, 2000. С. 251.
} 
Ш.-Л. Монтеск'є чітко визначає дві абсолютні цінності державного буття: абсолютно поганим є деспотизм, а абсолютно добрим - свобода. Забезпечення свободи зумовлює, на думку вченого, поділ влади в державі між трьома носіями влади, «інакше одна особа або об'єднання стануть могутніми настільки, щоб знищити свободу» ${ }^{6}$.

Французький мислитель Ж.-Ж. Руссо вказав, що природний стан $є$ станом «здорової байдужості»: людина не була ні доброю, ні злою, оскільки мораль як ціннісна категорія з'являється лише 3 державою. На вершині ієрархії цінностей Руссо знаходиться свобода, рівність. Суспільство і держава несуть негативні тенденції, оскільки вони розбещують людину. Найгіршою є втрата свободи, зумовлена соціальною нерівністю. Природна нерівність полягає в силі та розумі. Природна свобода, на його думку, позбавляє сенсу природну нерівність. Ціннісного значення нерівність набуває лише в державі. Ж.-Ж. Руссо переконаний, що розбудова держави призводить до відмови від свободи в обмін на ілюзорну захищеність - люди перетворюються на рабів держави. Він критикує державу за іiі узурпацію свободи ${ }^{7}$. Руссо вказував, що реалізувати свою свободу можна лише через урахування волі і прагнення інших людей. Свобода - це дуже велика відповідальність і за себе, і за ближніх, і за світ загалом ${ }^{8}$.

Філософські цінності сформувалися саме в кантівській традиції. Неокентіанці трактували філософію як вчення про загальнозначимі цінності ${ }^{10}$. І. Кант вважав, що цінності (морально) орієнтовані спонукання присутні у всіх моментах процесу пізнання, свідомість при цьому завжди спрямовується на категорії добра, досконалості та цінності. Цінності у його трактуванні - це те, що має значення в моральному світі обов'язковості і свободи.

Іншої думки був Г. Гегель, який розглядав сутність цінності через іiі зв'язок із потребами. Вказував, що кожна річ, за допомогою якої людина задовольняє потреби, має свою цінність. Якщо ми звертаємо увагу на

\footnotetext{
${ }^{6}$ Радченко О.В. Генезис розуміння державно-управлінських цінностей у політичній філософії від нового часу до кінця ХІХ ст. Теорія і практика державного управління. 2009. Вип. 1(24). С. 3.

${ }^{7}$ Рассел Б. История западной философии и ее связи с политическими и социальными условиями от Античности до наших дней: В трёх книгах. Издание 6-е, стереотипное. Москва : Академический проспект; Деловая книга, 2008. С. 839.

8 Карась А.Г. Роль релігійних цінностей у процесі формування права. Часопис Київського університету права. 2010. № 4. С. 60. URL: http://dspace.nbuv.gov.ua/bitstream/handle/123456789/ 23643/13-Karas.pdf

${ }^{9}$ Нагой Ф.Н. Теории ценностей и проблема целостности мировоззрения личности Вестник Пермского университета. Выпуск 1. Философия. Психология. Социология. 2017. C. 23 DOI: 10.17702/2078-7898/ 2017-1-20-28

${ }^{10}$ Виндельбанд В. От Канта до Ницше: История новой философии в ее связи с общей культурой и отдельными науками / пер. с нем. А.И. Введенского. Москва : КАНОН-пресс: Кучково поле, 1998. С. 387.
} 
значимість та цінність тої чи іншої речі, то сама ця річ виступає лише знаком і має значення не сама по собі, а як те, чого вона варта, тобто яку цінність становить у тій чи іншій конкретній ситуації. У Гегелівській концепції цінності має місце ідея «абсолютної цінності культури», яка характеризується нескінченною цінністю ${ }^{11}$.

Власні погляди щодо «ціннісної свободи» висловлював також і М. Вебер. Поняття «цінності» вчений порівнював із поняттям «парадигма», вважав, що наукові дослідження констатуються за допомогою ціннісних понять, при цьому наука як така має виступати незалежною цінністю ${ }^{12}$.

Натуралістична теорія цінностей розвинута в роботах американських філософів Р.Б. Перрі, Г. Беккера, Т. Парсонса, Р. Лінтона, К. Клакхона. Р.Б. Перрі поділяє цінності на істинні та хибні, розвинуті й нерозвинуті, складні й прості, позитивні і негативні, скриті й активні. Крім того, всі цінності він поділяв на повторні (статеві потреби, потреби в їжі, тощо) і прогресивні, котрі змінюються i розвиваються в міру їх задоволення (наприклад, слава); цінності також розрізняються між собою i за інтенсивністю, силою, тривалістю. А. Мейнонг спробував вивести «загальну теорію цінностей» і прагнув довести, що поряд 3 «особистими» $\epsilon$ «не особисті» цінності, які мають загальний характер, як-то цінність краси, добра та істини ${ }^{13}$.

Теоретик філософської антропології М. Шелер розрізняв цінності та їх носіїв. Цінності для нього - це об'єктивні якісні феномени, котрі не залежать від свідомості суб'єкта і від предметів, в яких вони проявляються. Цінності, на його думку, мають своїх носіїв, саме в них стають реальними, носіями ж виступають особистості та речі ${ }^{14}$.

Щодо «загальнолюдських цінностей», то варто вказати, що в західній філософській традиції обговорювалося питання ціннісного догматизму і релятивізму, можливості та необхідності звільнення науки від ціннісних суджень і перетворення етики та естетики на науку, а також проблематика позараціональної природи цінностей ${ }^{15}$.

Крім того, в науці сформувалися три підходи до розуміння природи цінностей: натуралістичний, інтуїтивістський та аксіологічний емотивізм чи нігілізм. У полі зору опинилися такі категорії: цінність, притаманна об'єктам, і самі об'єкти як цінність; конкретні та абстрактні цінності;

\footnotetext{
${ }^{11}$ Кавалеров А.А. Цінність у соціокультурній трансформації. Одеса : Асторпринт, 2002. С. 13.

12 Петінова О.Б. Проблема цінності в філософії. Культура народов Причерноморья. 2002. № 36. C. $185-188$.

${ }^{13}$ Там же. С. 186.

${ }^{14}$ Шелер М. Избранные произведения: сб. статей. Москва, 1994. С. 166-168, 341-342.

${ }^{15}$ Нагой Ф.Н. Теории ценностей и проблема целостности мировоззрения личности. Вестник Пермского университета. Выпуск 1. Философия. Психология. Соииология. 2017. С. 21. DOI: 10.17702/ 2078-7898/2017-1-20-28
} 
цінності як індивідуальна та надіндивідуальна реальність; зміст соціологізації та онтологізації природи надіндивідуальних цінностей; цінності як еталони поведінки чи ідеали; цінності, які являють собою чи то структури свідомості, чи то структуру мотивації. 3 огляду на це виділяють три форми існування цінностей: суспільні ідеали; їх предметне втілення в діях та поведінці конкретних осіб; мотиваційні компоненти особистості як «взірці належного» 16.

Цінність, будучи даною чи заданою, кожного разу заново відкривається особистістю чи ігнорується нею. Становлення особистості відбувається в процесі поєднання соціалізації та індивідуалізації. Аксіологія орієнтує гуманітарне пізнання на аналіз феноменів особистості та індивідуальності, тобто на те, що робить людину людиною, породжує сенс як «виправдання» людського буття. Важлива роль у цьому належить творчості, що може створювати як матеріальні, так і духовні цінності ${ }^{17}$.

Дослідник В.А. Карташкін вважає, що для індивіда, держави та суспільства $є$ корисним те, що служить для їх інтересів, та сприяє їх розвитку $^{18}$, тоді як А.М. Руденко вказує, що «в цінностях відображені пласти народної культури, особливості менталітету i конкретного повсякденного побуту життя людини» ${ }^{19}$.

М. Карган вважає, що цінність - це внутрішній, емоційно засвоєний суб’єктом орієнтир діяльності людини, а тому цінність сприймається ним як його власна духовна інтенція. Роль цінностей у суспільному й культурному житті, на думку М. Кагана, двовимірна, вона виявляється в суб'єктно-об'єктних та міжсуб'єктних відносинах. Цінності скеровують, орієнтують, регулюють стосунки людей, тому сприятливе середовище для засвоєння цінностей є важливим ${ }^{20}$.

С. Анісімов розглядає цінності як категорії, які виражають абсолютну, ідеальну досконалість, за допомогою яких суспільство виробляє більш чи менш стабільну систему визначених цінностей, критерій оцінки найбільш важливих елементів людського буття. Дослідниця Куніцина під цінностями розуміє соціальні явища, що мають позитивну певну значущість для людей, а також можуть бути об’єктом їх діяльності ${ }^{21}$.

${ }^{16}$ Там само. С. 21.

${ }^{17}$ Там само. С. 22.

${ }^{18}$ Карташкин В. А. Универсализация прав человека и традиционные ценности человечества. Современное право. 2012. № 8. С. 3-9.

${ }^{19}$ Руденко А.М. Социовитальные ценности смысложизненной интенциональности екзистенции человека. Экономические и гуманитарные исследования регионов. 2012. № 3. С. 165-172.

${ }^{20}$ Каган М.С. Философская теория ценностей. Лекции. Санкт-Петербург : ТОО ТК Петрополис, 1997. $205 \mathrm{c}$.

${ }^{21}$ Гуманізація навчально-виховного процесу. Спецвипуск 4. Ч. 2. Слов’янськ, 2010. 54 с. 
У дослідженнях таких вчених, як В. Сержантов, Т. Скрябінова, В. Шадріков та $€$. Клімов, цінності $є$ важливим механізмом регуляції діяльності індивіда, особистості ${ }^{22}$.

Досить часто поняття «цінності» тлумачиться як значущі для індивіда чи суспільства предмети, явища або ж події (Р. Перрі, Л. Баєва, Л. Титаренко, М. Михальченко, П. Сліпець). Також цінність розглядається як предмет, який $є$ корисним і здатним задовольнити певні потреби (А. Маслоу); як норма, якої варто притримуватися (О. Краєва, М. Михальченко, Л. ОлбранЛембрик); як ідеал, до якого прагне людина (Е. Фромм, Г. Лотце). Також із-поміж цінностей розрізняють об'єктивні (природні явища, матеріальні предмети, суспільні відносини) та суб'єктивні (настанови, ідеали, оцінки, орієнтації), загальнолюдські, суспільні, політичні, особистісні, внутрішні (екзистенціальні) та зовнішні. Усі ці трактування відбивають певні особливості цінностей.

Не всі вчені здійснюють класифікацію та ієрархію цінностей. О. Сидорова вказує, що цінності між собою є рівнозначними, крім того, правові цінності, на ії думку, мають виражатися одна через одну. Так, свобода виражається через феномен безпеки, а правосуддя можна охарактеризувати через зміст правопорядку ${ }^{23}$.

Загальновживаним є розподіл цінностей на матеріальні та духовні. Такий поділ грунтується на критеріях потреб та інтересів людей (онтологічний підхід). Поділ цінностей на дві категорії спостерігаємо і за гносеологічним підходом. Так, усі цінності поділяються на предметні та суб'єктні. До предметних належать предмети людської діяльності, різного роду суспільні відносини, а також включені до їх кола природні явища, як об'єкти. Суб'єктні цінності становлять оцінки та установки, заборони та зобов'язання, проекти та цілі, які виражені у формі нормативних уявлень.

Болгарський вчений Н. Неновскі вважає: «Ціннісними критеріями у сфері права $є$ суспільні інтереси і потреби, ідеально усвідомлені, і перетворені на принципи, цілі та ідеали» ${ }^{24}$.

Дослідник О. Мартишин всі цінності ділить на універсальні та прикладні, серед яких найбільш загальними правовими цінностями вважає державу i права. Спеціальні цінності мають забезпечувати окремі аспекти держави i права. До них належать: права людини, рівність, законність, демократизм, презумпція невинності та інші. Ці цінності, на думку вченого, є правовою формою таких універсальних цінностей, як свобода і рівність ${ }^{25}$.

\footnotetext{
22 Бабенко Ю. Теоретичні аспекти дослідження цінностей. Вісник Національної академії керівних кадрів культури і мистеитвв. 2013. № 3. C. 93. URL: http://nbuv.gov.ua/UJRN/vdakkkm_2013_3_23.

${ }_{23}^{23}$ Сидорова Е.В. Миф о правовых ценностях История государства и права. 2012. № 11. С. $24-26$.

${ }^{24}$ Неновски Н. Право и ценности: пер. с болг. Москва : Прогресс, 1987. С. 152.

25 Мартышин О.В. Проблемы ценностей в теории государства и права. Государство и право. 2004. № 10. C. 7 .
} 
Німецький дослідник Г. Радбрух виділяє три найвищих цінності: етична (добро), логічна (істина) та естетична (краса). Він вказує, що етичній цінності (добру), що вбирає в себе інші абсолютні цінності - естетичну та логічну, служить право. Крім того, він розрізняе також види цінностей: індивідуальні цінності, колективні цінності та творчі цінності ${ }^{26}$.

Залежно від сфер впливу на процес життєдіяльності людини та етапи виникнення людських знань на цінності покладаються такі функції: поперше, аксіологічна, згідно з якою визначається, що цінність $є$ умовою процесу життєдіяльності людини та етапом оформлення людського знання; по-друге, світоглядна, яка визначає цінність як одну з форм відображення дійсності, при якій формується світогляд людини; по-третє, соціальна, згідно з якою цінність виступає інструментом чи формою міжособистісних відносин у суспільстві. Вона $є$ способом пристосування людей до умов соціальної дійсності. Цінність також являє собою певний алгоритм та програму творчих змін суспільства; по-четверте, культурнорепродуктивна, за якою цінність $є$ способом передачі та репродукції матеріалів культури. Ця функція забезпечує можливість збереження, поширення та відтворення цінностей; по-п'яте, культурно-формотворча, згідно з якою цінність виступає і як джерело, і як засіб створення типів культури взагалі; по-шосте, комунікативна, згідно 3 якою цінність орієнтована на комунікацію; по-сьоме, цінність, яка $\epsilon$ актуальною протягом тривалого проміжку часу і сприймається як абсолютна цінність, належить до трансісторичних функцій ${ }^{27}$. Цінність тісно пов'язана $з$ такими категоріями, як «краса», «істина», «добро». «Краса» $\epsilon$ естетичною цінністю, «добро» належить до моральних цінностей, а «істина» - це пізнавальна цінність. Л.Н. Столович наголошує на взаємопроникненні всіх цінностей в естетичну цінність. Автор доводить, що естетичні цінності утворюють з іншими цінностями комплексні ціннісні симбіози: естетикоутилітарний (мистецтво, дизайн, архітектура); естетико-пізнавальний, предметом дослідження якого виступає естетична значимість суспільних відносин; естетико-пізнавальний, що вказує на витончену форму, красивий експеримент; естетико-моральний, який визначає красу поведінки ${ }^{28}$.

Красиве, прекрасне $є$ категоріями естетики, що відображають гідні вищої естетичної оцінки властивості людини та іiі творчої діяльності, природи та суспільного життя. Різниця між красивим та прекрасним полягає в роді естетичного феномена: людина може бути прекрасною, проте некрасивою i, навпаки, красива людина не завжди прекрасна.

\footnotetext{
${ }^{26}$ Радбрух Г. Философия права: пер. с нем. Москва : Междунар. отношения, 2004. С. 65.

${ }^{27}$ Невмержицька О.М. Релігійно-філософська естетична аксіологія : дис. ... канд. філософ. наук : 09.00.11. Київ, 2019. С. 23.

${ }^{28}$ Столович Л.Н. Философия, Эстетика, Смех. С. Петербург, Тарту, 1999. С. 192.
} 
У процесі естетичного розвитку індивіда виникає естетична установка, так званий «естетичний смак», формується «естетичний ідеал». Естетичний ідеал як образ зразкового $є$ системою уявлень, образом належної естетичної цінності.

Н. Гартман вважає, що цінності призначені для того, щоб явити повноту життя людини, дозволити їй перейти від буття до благо-буття і прекраснобуття, сприймаючи життя як таке ${ }^{29}$. Він вказує, що цінності надають життю сенсу, виправдовуючи існування індивіда, через якого тільки вони і можуть бути виявлені. (Так, одна людина, споглядаючи ліс, бачить його ринкову красу, інша із захопленням говорить про його красу). Поки є хоч один суб'єкт, що споглядає прекрасне, існує і прекрасне як цінність і як реальність в об'єкті.

Моральні цінності - це вид цінностей, відмінний від естетичних, проте вони так само, як і естетичні, потребують іншого носія - людини як суб'єкта свідомості. Моральні цінності можуть з'явитися тільки там, де проявляються якісь інші визначені цінності. 3-поміж моральних можемо виділити: справедливість, дієвість, чемність, скромність, внутрішню покору, відповідальність, вірність, милосердя, шляхетність, здатність зробити щось, не вимагаючи за це платні. Усі моральні цінності характеризують чи то особу, чи то іiі дії, а можливо, є актом волі. Р. Інгарден стверджує, що моральні цінності завжди стосуються або людей, або людських вчинків. Вони відрізняються від естетичних. Моральним притаманний обов'язковий характер, вони вимагають власної реалізації, адже людина завжди перебуває в певній життєвій ситуації, в якій завжди ставить завдання як перед собою, так i перед іншими. I конкретний вчинок у тій чи іншій ситуації завжди матиме моральноціннісну характеристику - позитивну чи негативну ${ }^{30}$.

Т. Аболіна тлумачить моральні цінності так: 1) осмислені моральною свідомістю, етично обгрунтовані, належні доброчесності та відповідні для них норми поведінки, такі як мудрість, толерантність, вірність, толерантність, щирість, правдивість, мужність; 2) узагальнений зміст основних етичних понять - добро, зло, справедливість, щастя, гідність, честь, обов'язок, альтруїзм, гуманізм, благоговіння перед життям; 3) безпосередньо значимі для людини універсальні зразки, вимоги, ідеали моралі, які мають самостійний статус, схвалюються суспільною думкою, знаходять втілення в праві, релігії, мистецтві, філософіiї

\footnotetext{
${ }^{29}$ Гартман Н. Эстетика. Київ : Ника-Центр, 2004. 640 с. С. 435, 454.

${ }^{30}$ Ingarden R. Studia z estetyki / R. Ingarden. T. 1. Warszawa : PWN, 1957. S. 241-242.

31 Філософський енциклопедичний словник / редкол.: В.І. Шинкарук. Національна академія наук, Інститут філософії імені Г.С. Сковороди. Київ : Абріс, 2002. С. 708.
} 
Поняття «цінність» у культурології $є$ найважливішим компонентом людської культури поряд із нормативами та ідеалами. Їх функціонування походить від екзистенціальної активності суб'єкта, культурної творчості в його діалозі з іншими людьми, який зорієнтований як на галузь істотного, так і на значуще, нормативно належне. Тут цінністю $є$ позитивна чи негативна значимість об’єктів оточуючого світу для індивіда, різних соціальних груп чи суспільства загалом, яке зумовлене їх значимістю у сфері людської життєдіяльності, потреб чи інтересів. у культурології цінності стоять на одному щаблі поряд 3 ідеалами та нормами. Культурологи завжди співвідносили і співвідносять цінності з такими поняттями, як «культура» та «культурні потреби особистості». К. Левицька зазначила, що такий науковець, як Г. Хофстеде, запропонував розглядати цінності як осередок індивідуальної та суспільної культури ${ }^{32}$.

Ми дотримуємося думки, що цінності $є$ фундаментом культури. Охоплюючи потреби, інтереси та емоційні переживання суб'єкта, вони часто виконують роль підстави для вибору цілей і засобів у процесі здійснення певної діяльності, а також сприяють формуванню психології людини, ментальності, способу життя членів суспільства, включають у себе досвід, що базується на певних знаннях, та поведінку ${ }^{33}$.

Ю. Шайгородський підкреслює, що цінності є своєрідним культурним кодом, який забезпечує відповідний процес культурної ідентифікації як окремої особистості, так і цілого народу чи нації ${ }^{34}$. Так, ціннісна самоідентифікація визначає унікальність та самобутність нації. Духовна культура при цьому є носієм матеріальних та духовних надбань, які відображають рівень розвитку суспільства та впроваджуються в процесі духовного виробництва.

Характеризуючи цінності, зазначимо, що в системі цінностей значне місце відводиться духовним цінностям. Духовні цінності від інших цінностей відрізняються тим, що вони $\epsilon$ продуктом духовного виробництва, належать до феноменів свідомості та виражаються у формі соціокультурних орієнтирів, таких як норми, символи, ідеали, почуття, образи, які зумовлюють розвиток як окремого індивіда, так і суспільства загалом. Духовні цінності варто розглядати і як продукт діяльності, як орієнтири, що визначають сенс буття; духовні цінності невіддільні від нормативно-моральної регуляції людської поведінки; духовні цінності $\epsilon$

\footnotetext{
32 Левківська К.В. Ціннісні засади діяльності освітніх закладів : навч.-метод. посібник. Житомир : Вид-во ЖДУ, 2017. 136 с.

${ }^{33}$ Качур В.О. До визначення поняття «правова культура» у правознавстві. Право. Людина. Довкілля: науково-практичний журнал. 2019. № 10(1). C. 16. DOI: http://dx.doi.org/10.31548/law2019.01.002

34 Шайгородський Ю.Ж. Ціннісний конструкт міжкультурної комунікації. Украӥнський соичіум. 2002. № 1. C. 41-48.
} 
вершиною досягнення людства, а також виступають як внутрішні переконання, $\epsilon$ результатом довготривалої соціалізації та процесу виховання людини.

У дисертаційному дослідженні М. Блікхар вказує такі підходи до розуміння духовних цінностей, де вони розуміються як щось цінне, важливе, значуще для людини, соціальної групи, в духовній сфері (моральні принципи, політичні ідеї, патріотичні переживання (В. Москалець), психічні новоутворення, які відображають значущі для суб'єкта узагальнену сферу людського та природного довкілля (I. Бех), продукти духовної діяльності, вартість яких не зменшується та не зникає внаслідок їх споживання (С. Черепанов), гуманістичні життєві орієнтири, які спонукають людину до дій, впливають на особистісний вибір, допомагають подолати негативні риси в собі, спричиняють потребу у справедливості, повагу до людської та власної гідності, спрямовують на морально-етичні відносини соціуму (С. Гусаківська), конструктивні орієнтири людської свідомості, які визначають норми поведінки особистості (О. Шкіренко) ${ }^{35}$.

Значення духовних цінностей важко переоцінити. Вони можуть виступати інститутами соціального регулювання суспільства, пов'язувати поведінку людини з iї ідеалами, сприяти формуванню в людей та їх спільнот потреби в пізнанні світу та інших суб'єктів, впливати на стан економічного, політичного розвитку суспільства.

Дослідник П. Сорокін стверджує, що основу та фундамент будь-якої культури становлять цінності релігії, економічна цінність землі, цінності науки, освіти, демократії, здоров'я, життя та інші. Вчений наголошує на тому, що культура не може довго розвиватися на одному й тому самому ціннісному грунті. Перехід від однієї культури до іншої супроводжується кризою, коли ламаються старі ідеали та утверджуються нові ${ }^{36}$. У цінностях відображені пласти народної культури, особливості ментальності та конкретного повсякденного побуту людини.

Гуманістичні цінності, на думку I. Беха, характеризують індивідуальну культуру особистості та рівень ii вихованості: любов, добро, справедливість, совість, патріотизм, милосердя, відповідальність є взаємопов'язаними, вони взаємопроникають та взаємодоповнюють одна одну. За допомогою гуманістичних цінностей забезпечується оволодіння нормами та правилами взаємодії з оточуючими. Гуманістичні цінності, на

\footnotetext{
35 Блікхар М.П. Духовні цінності студентської молоді в сучасному українському суспільстві : дис. ... канд. соціолог. наук : 22.00.04 / Львівський національний університет імені Івана Франка. Львів, 2018. C. 89 .

${ }^{36}$ История социологии в Западной Европе и США. Москва : Наука, 1993. С. 344.
} 
відміну від моральних цінностей, що орієнтовані на саму людину, власний духовний світ, спрямовані на інших людей, реалізуються заради інших ${ }^{37}$.

Досліджуючи теорію цінностей, зазначимо, що ця проблематика останнім часом значно розширилася, з'явилося чимало нових відгалужень в аксіології, які конкретно та детально досліджують окремі аспекти цінностей. Так, з'явилися і активно розвиваються теологічна аксіологія $\left(\right.$ М. Блікхар ${ }^{38}$ ), яка досліджує цінності індивіда через дотичність із релігією, мораллю, політична аксіологія, що виокремлює та аналізує ціннісні характеристики індивіда в суспільній (А. Ручка ${ }^{39}$ ) та політичній сферах (I. Жеребятнікова ${ }^{40}$, О. Радченко ${ }^{41}$ ); економічна аксіологія вивчає категорії економічного багатства (цінності), досліджує важливість певних благ та їх цінність для економічного розвитку і якості людського розвитку (Л. Глубіш ${ }^{42}$, О. Діденко ${ }^{43}$ ); педагогічна аксіологія здійснює пошук ефективних засобів для здійснення навчального процесу та виховання шкільної та юнацької молоді (Т. Калюжна ${ }^{44}$ ).

Дослідник К. Клакхон визначав цінності як «усвідомлене і неусвідомлене, характерне для індивіда чи певної групи осіб, яке визначає вибір цілей як групових, так і індивідуальних з урахуванням можливих способів та засобів дій. Вчений виокремив три групи культурних цінностей: цінності, які стосуються становища людини в природі «людини і природа»; цінності, які стосуються відносин людей між собою «людиналюдина»; цінності, які стосуються як міжособистісних відносин, так і відносин людини і природи «про природу і про людину».

Дослідник Г. Хофстеде запропонував класифікацію культур, які необхідні для вивчення цінностей індивідуалізму і колективізму. Так, всі

\footnotetext{
${ }^{37}$ Бех І.Д. Виховання особистості: сходження до духовності. Київ : Либідь, 2006. С. 10.

${ }^{38}$ Блікхар М.П. Духовні цінності студентської молоді в сучасному українському суспільстві : дис. ... канд. соціолог. наук : 22.00.04 / Львівський національний університет імені Івана Франка. Львів, 2018. C. 89.

${ }^{39}$ Ручка А. Цінності та ціннісна зміна у сучасному суспільстві. Прикладна культурологія $і$ культурні практики. Культурологічна думка, 2013.

40 Жеребятнікова І.В. Цінності політичного життя у сучасному українському соціумі. Вісник Харківського національного університету імені В.Н. Каразіна. Серія: Питання політології 2013. № 1060, вип. 23. С. 52-59. URL: http://nbuv.gov.ua/UJRN/VKhIPP_2013_1060_23_12.

${ }_{41}$ Радченко О.В. Цінність в системі державного управління: категоріальний аспект. Державне будівниитво. 2008. № 2. URL: http://nbuv.gov.ua/UJRN/DeBu_2008_2_6

${ }^{42}$ Глубіш Л. Система цінностей як базис формування економічних інтересів стейкхолдерів як вектор економічних ефектів від їх реалізації. Економіка і суспільство. 2017. Випуск № 9. С. 171-175. URL: http://www.economyandsociety.in.ua/journal/9_ukr/29.pdf.

43 Діденко О. Виклики сучасності, тенденції та проблеми професійного виховання майбутніх офіцерів-прикордонників. Збірник наукових праиь Національної академії Державної прикордонної служби України. Серія : Педагогічні науки. 2016. № 1. С. 70-81. URL: http://nbuv.gov.ua/UJRN/ znpnadpcpn_2016_1_8

${ }^{44}$ Калюжна Т.Г. Педагогічна аксіологія в умовах модернізації професійно-педагогічної освіти : монографія / за наук. ред. О.В. Уваркіної. Київ : Вид-во НПУ імені М.П. Драгоманова, 2012. 128 с.
} 
культури автор поділив на три групи: 1) західні, що характеризуються розвиненим індивідуалізмом; 2) східні, яким притаманний колективізм; 3) змішані з різним ступенем індивідуалізму та колективізму ${ }^{45}$.

Основний аналіз цінностей у політичній науці пов'язаний із вивченням політичного мислення. У сучасних політичних виданнях під «політичними цінностями» розуміють погляди, переконання суб'єктів політики щодо важливих для них політичних явищ, процесів та інтересів, складову систему цінностей; цінності - найважливіші компоненти людської культури, які мають вищу значущість для людини та людства, в різні історичні періоди наповнюються конкретним змістом і зумовлюють зразки та стандарти поведінки; політичні цінності - це ідеї, що зумовлені політичними потребами суб'єктів політичного життя, - людей, груп, партій, суспільства ${ }^{46}$. Цінності в політології та економіці вивчаються на макро- та мікрорівнях.

Така наука, як соціологія, велику увагу приділяє дослідженню та вивченню природи цінностей. Оскільки предметом вивчення соціології $\epsilon$ людина в іiі співвідношенні з суспільством та культурою, вона $\epsilon$ також наукою про цінності як людини, так і суспільства. Цінності в соціології це основні моральні та естетичні норми, які виконують як регулятивну, так і прогностичну функції.

Цінність знаходиться між об'єктом та суб'єктом, одночасно протиставляючи і поєднуючи їх. Цінність є людським надбанням, вона категоріальна характеристика його специфічної сутності. Сама система цінностей визначає цілі, а через практичну діяльність реалізується в якості матеріального та духовного буття.

Е. Гіденс трактує цінності як уявлення окремих індивідів чи окремих груп про бажане, прийнятне, схвальне. Н. Смельзер веде мову про цінності як про наявні в суспільстві переконання щодо цілей, до яких люди мають прагнути, і як основні засоби їх досягнення ${ }^{47}$.

Соціолог М. Вебер зазначав, що цінності, по-перше, впливають не лише на пізнання та оцінку різних явищ, по-друге, вони визначають норми стосунків людей, по-третє, устрій суспільного життя, по-четверте, цінності визначають вплив на характер культури суспільства. Як зазначає Р. Айрон, М. Вебер вважав: «Людське життя пов'язане 3 необхідністю постійно

\footnotetext{
45 Блікхар М.П. Духовні цінності студентської молоді в сучасному українському суспільстві : дис. ... канд. соціолог. наук : 22.00.04 / Львівський національний університет імені Івана Франка. Львів, 2018. С. 54.

46 Ярошко О.3. Цінність як наукова категорія. Європейські культурно-історичні иінності: ретроспектива і перспектива : збірник наук. пр. / за заг. ред. О.В. Зернецької; Державна установа «Інститут всесвітньої історії НАН України». Київ : ДУ «Інститут всесвітньої історії НАН України», 2018. C. 52.

${ }^{47}$ Смельзер Н. Соціологія. Москва : Феникс, 1994. С. 660.
} 
робити вибір, що зумовлює систему цінностей $<\ldots>$ Вони [цінності] $\epsilon$ довільно проектовані людиною явища, наслідок ухвал...» ${ }^{48}$. Німецький соціолог розумів під цінностями узагальнені цілі та певні способи їх досягнення, які сприяють інтеграції суспільства. Вебер поділяє цінності на мирські та вищі, де мирські становлять напрям інтересу епохи, а вищі своєю чергою знаходяться поза часом, оскільки їх реалізація не залежить від часу. У своєму вченні М. Вебер розмежовує акти: «співвідношення $з$ цінністю» та оцінку.

Французький соціолог Е. Дюркгейм у працях «Ціннісні та реальні судження» та «Соціологія і філософія» вказував, що цінності - це ідеали, які є основними рушіями поведінки людини, на основі яких формуються як цілі суспільства, так і цілі цивілізації. Він вважав цінностями ідеали, «колективні уявлення», які виступають рушієм поведінки, за якими стоять діючі і реальні колективні сили. Він вказував, що на великих ціннісних ідеалах базується цивілізація. Він стверджував, що народження цінностей $\epsilon$ соціальним актом, оскільки суспільство є середовищем, де народжуються цінностін ${ }^{49}$.

Вчений у працях аналізував взаємні впливи нормативних систем суспільства та особи, підкреслював, що система цінностей суспільства складається із сукупності окремих ціннісних систем кожного $з$ членів цього суспільства. 3-поміж всіх цінностей він виділяє економічні, моральні, релігійні, естетичні та фізичні.

Соціолог Т. Парсонс розглядає цінності як вищі принципи, які забезпечують згоду як у малих соціальних групах, так і в суспільстві загалом, конструюють модель соціальної системи, а соціальні цінності - як продукти культури. Цінності для нього є нормативним стандартом, який визначає бажану поведінку. Система цінностей існує в кожній соціальній системі, вона одночасно об'єднує і розділяє людей, оскільки сприяє виникненню різних соціальних класів, верств, націй та народів ${ }^{50}$.

Е. Гідденс зазначає: «Людина в глобальному світі $\epsilon$ незахищеною традиціями своєї культури, 3 огляду на це ій доводиться керуватися загальнолюдськими цінностями». Він вказує, що в процесі глобалізації світ наповнюється псевдоцінностями, через що особі дуже важко виокремити для себе ті цінності, які для неї є справді значущі ${ }^{51}$.

\footnotetext{
${ }^{48}$ Арон Р. Етапи розвитку соціологічної думки / пер. $з$ фр. Г. Філіпчука. Київ : Юніверс, 2004. С. 535.

${ }^{49}$ Дюркгейм Э. Ценностные и «реальные» суждения. Соц. исследования. 1991. № 2. С. 106-114.

${ }^{50}$ Кавалеров А.А. Цінність у соціокультурній трансформації : монограф. Одеса : Астропринт, 2001. C. 138.

51 Гидденс Э. Ускользающий мир: как глобализация изменяет нашу жизнь / пер. с англ. М.Л. Коробочкина. Москва : Весь мир, 2004. С. 120, 63.
} 
Дослідники Дж. Катон, У. Ростоу, О. Тоффлер, Х. Ортега-і-Гассет, Г. Маркузе, Т. Адорно у працях вказують, що споживання зумовлене певною системою цінностей, які притаманні тій чи іншій культурі. Так, для постмодерного суспільства характерним $є$ те, що ціннісний контекст споживання репрезентується через призму стилів життя, а також через аналіз споживання «символічного обміну» ${ }^{52}$.

Вчені доводять, що споживачі, які зорієнтовані на внутрішні цінності, такі як самоповага, самореалізація, хвилювання тощо, прагнуть контролювати своє життя, дуже часто приймають незалежні рішення. А ті споживачі, які мають зовнішню орієнтацію, для яких характерними $є$ такі цінності, як безпека, повага з боку інших, відчуття приналежності, мають схильність погоджувати власну купівельну поведінку з думкою більшої частини суспільства. Акт споживання набуває рис соціальної дії, включеної в соціальний обмін як процес комунікації в рамках того чи іншого соціокультурного простору, при якому головним цінностями виступають зв'язки, успіх, статус у суспільстві, мода чи престиж.

Зворотною стороною цього, на думку Дж. Рітцера, $\epsilon$ «процес макдональдизації», яка є ознакою глобального суспільства. Основними цінностями $є$ ефективність, розрахунковість, контроль та передбачуваність. Споживацтво має власну систему цінностей, коли на вершині споживання знаходяться цінності гедоністичного спрямування, націлені на задоволення власних, егоїстичних потреб. А. Етціоні вказує на те, що матеріальні об'єкти стають предметом пристрасті, засобом самоствердження людини чи піднімають прагнення до самовираження ${ }^{53}$.

Варто звернути увагу і на те, що посилюється вплив символічного аспекту споживання, цінністю $є$ не сам по собі товар, а річ, реакція, враження, яке вони викликають у споживачів. У сучасному суспільстві великого значення набувають цінність зелених товарів, підхід до вираженого ставлення до купівлі, повторне використання вже придбаних речей. Це спричиняє формування нового поняття «міри» як цінності, яка може протидіяти незбалансованому та незбалансованому споживанню.

У наукових доробках Р. Інглегарт вказує, що залежність моральнодуховних цінностей від економічних чинників неоднозначна, це зумовлено системою цінностей родини, в якій виховується особистість, а також ціннісними традиціями соціуму, ментальністю самого народу, моральними принципами авторитетів або ж навчанням.

Соціолог Є.Головах стверджує, що цінності громадянського суспільства, поваги до закону, прав людини та інтересів особистості,

52 Пачковський Ю.Ф. Максименко А.О. Споживча поведінка українських домогосподарств : монографія. Львів : ЛНУ ім. І. Франка, 2014. С. 64.

53 Этциони А. Что придет на смену консьюмеризма? Свободная мыслль XXI. 2009. № 8. С. 55. 
толерантності, захисту людей 3 обмеженими можливостями чи прав нацменшин не поширені в масовій свідомості, що перебуває під сильним впливом економічної, політичної та духовної культури суспільства. Згідно 3 «European Social Survey», в українському суспільстві домінують цінності «відкритості до змін». На думку Є. Головахи, цінності українського суспільства не залишаються незмінними. Так, у ціннісному полі українців співіснує прагнення до вступу в Свропейську Співдружність наряду 3 пострадянськими цінностями патерналізму. Г. Клагес запропонував так званий «ціннісний синтез», при якому співіснують старі та нові цінності, які не протистоять одна одній, а створюють продуктивну взаємодію ${ }^{54}$.

Відомий американський соціолог Н. Смелзер вважає, що цінності є свого роду індикатором людського поступу, вони завжди утворюють певну ціннісну систему. Кожне суспільство має специфічну структуру цінностей, власні «основні» цінності, які визначають його подальший розвиток, місце в політичних та соціальних системах.

Таким чином, ми спостерігаємо плюралізм наукового розуміння поняття «цінність», який на початку $\mathrm{XX}$ ст. дав підстави визначати його центральною категорією культури в розумінні останньої як «світу втілених цінностей». Цю тенденцію ми спостерігаємо і на початку XXI ст., де вони виконують роль своєрідного культурного «коду» чи розглядаються як фундамент культури.

Складність та неоднозначність цього поняття зумовлюється тим, що воно є об'єктом і предметом вивчення безлічі наук, серед яких філософія, психологія, соціологія, політологія, право, економіка та ін. Швидке утвердження «принципу цінності» як умови пізнання і розуміння культури не вирішило проблеми виявлення власного змісту категорії «цінність» i залишило іiі природу неоднозначною і дотепер ${ }^{55}$. За оцінками Р. Лаутмана, у соціальній науковій літературі $є$ понад 4 тисячі праць, в яких автори звертаються до поняття «цінності» 56.

Аналіз вітчизняних наукових розвідок останніх років у різних сферах наукового знання також засвідчує, що деякі автори часто-густо здійснюють взаємозаміну чи не диференціюють поняття «цінність», «антицінність», «благо», «ідеал», «істина», «норма поведінки», «смисл», «потреба» тощо або використовують термін «цінність»у назвах наукових

\footnotetext{
${ }^{54}$ Гаврилишин Б. До ефективних суспільств: Дороговкази в майбутнє: доповідь Римському Клубові. Вид. 3-те, допов. Київ : Унів. вид-во «ПУЛЬСАРИ», 2009. С. 21-22.

${ }^{55}$ Стасевич В.П. Цінність як категорія і принцип осмислення культури. URL: http://ea.donntu.org:8080/ jspui/bitstream/123456789/1544/17/stasevich.htm.

56 Горбатюк С.С. Теорія цінностей як методологічна основа аксіології соціогуманітарної безпеки. Вісник Наџіональної академії державного управління при Президентові України. Серія : Державне управління. 2016. № 4. С. 22.
} 
праць для того, щоб «привабити» потенційного читача. Про таку небезпеку, коли «втрачається специфіка проблеми цінності», говорив ще в 60-х роках XIX ст. В. Василенко, який вважав за доцільне використовувати категорію «цінність», якщо «за нею буде закріплене певне пізнавальне навантаження» i «вона буде належати до тих аспектів реальності, які не охоплюються іншими категоріями філософії 57 .

Здійснений нами аналіз феномена цінності дав змогу виокремити такі іiі властивості: 1) ключовою ознакою категорії «цінність» є іiї «значимість» («значущість», «значення»); 2) цінності суб’єкт вибудовує в процесі своєї життєдіяльності, починаючи зі стадії цілепокладання; 3) когнітивним компонентом цінності виступають знання, які дають змогу суб'єкту виокремити властивості явища, які будуть оцінені ним на предмет їх значущості; 4) емоційним компонентом цінності є оцінка, за допомогою якої суб'єкт лише фіксує належне, стверджує свій інтерес та з'ясовує, чи це відповідає його потребам і тим самим є значущим для нього; 5) оцінка $€$ процесом чи процедурою надання певним явищам цінності (поцінування або заперечення), розглядається як передумова встановлення цінності і складається з суб'єкта та об'єкта оцінки, а також іiі об'єктивної та суб'єктивної сторони; 6) цінність не можна окремо ототожнювати ні 3 суб'єктом та його потребами, ні з об'єктом оцінки, наділеним певними властивостями, оскільки самі по собі вони цінності не дають; 7) процес чи процедура встановлення цінності передбачає виконання послідовно певних розумово-емоційних дій; 8) цінності мають суто соціальну природу; 9) одне і те саме явище може мати різну цінність для різних суб'єктів ${ }^{58}$.

Це дає підстави визначати цінності як явища об'єктивного світу (матеріальні та духовні), що мають значення для суб'єкта під час здійснення ним життєвого вибору.

\section{2. Де шукати місце цінностей у теорії правової культури?}

Людська історія засвідчує, що перед суспільством кожного разу постають різного роду виклики, які нині прийнято називати глобалізаційними (світова економічна криза, екологічні катастрофи, війни та ін.). Цьогоріч цей перелік поповнився новим випробуванням - COVID-19. Крім глобалізаційних викликів, кожна держава має власні виклики часу, зумовлені соціальними проявами (безробіття, трудова міграція, знецінення праці, слабкий соціальний діалог та соціальна згуртованість) та подіями (анексія Криму та

\footnotetext{
57 Василенко В.А. Ценность и ценностные отношения. Проблема иченности в философии. МоскваЛенинград : Издательство «Наука, 1966. С. 42.

${ }^{58}$ Качур В.О. Категорія «цінність» у теорії правової культури: до визначення поняття. Право. Людина. Довкілля: науково-практичний журнал. 2020. № 11(1). C. 10. DOI: http://dx.doi.org/10.31548/ law2020.01.001
} 
військові конфлікти). У будь-якому разі такі виклики змушують людство переосмислювати цінності, а також роль держави і права в їх подоланні. Таке переосмислення ми спостерігаємо як на буденному, так і на науковому рівні. Але незалежно від рівня, на якому відбувається такий процес, з'єднувальною ланкою між ними буде правова культура, що відіграє важливу роль не лише у формуванні громадянського суспільства, а й у житті окремої людини та в історії людства загалом.

Науковий інтерес до правової культури, який ми спостерігаємо в наукових дослідженнях, дає підстави говорити про існування окремого загальнотеоретичного наукового напряму «теорія правової культури». Це зумовлюється і тією роллю, яку вона виконує нині, і тими завданнями, які стоять перед нею: 1) збереження та накопичення правового досвіду (так звана «правова пам'ять»); 2) передача правового досвіду від покоління до покоління (так званий «правовий поступ»); 3) залучення індивіда до системи правових цінностей (так звана «правова соціалізація»).

У теорії правової культури поняття «цінність» ми можемо вживати, коли йдеться про цінність правової культури (властивість правової культури. що дає змогу розкрити іiі сутність як суспільно-історичного явища, що забезпечує ефективність правового регулювання), цінності правової культури (явища об'єктивного світу, що дають змогу розкрити цінність правової культури) та правові цінності (фундамент правової культури).

У межах цієї наукової розвідки ми спробуємо з'ясувати: 1) що таке правова культура; 2) що становить структуру правової культури; 3) яке місце в цій структурі займають цінності.

Досліджуючи поняття «правова культура», ми зіткнулися з наявністю понад 500 дефініцій цього поняття, безліччю наукових статей, в яких науковці-одинаки наважувалися дати хоч яке-небудь авторське визначення цього поняття. Це можна пояснити тим, що, по-перше, розуміння правової культури залежить від того, який методологічний підхід до ії дослідження використовує той чи інший учений, по-друге, це поняття характеризується полісемантичністю, по-третє, включає в себе два слова «культура» i «право», які своєю чергою $є$ неоднозначними.

Незважаючи на те, що правова культура $є$ широко вживаною категорією, варто констатувати про відсутність однозначного методологічного підходу до іiі розуміння. Так, нині виокремлюють такі підходи до пізнання культури і правової культури: філософський, соціологічний, аксіологічний, антропологічний, культурологічний, діяльнісний, цивілізаційний, системний, структурно-функціональний, суб'єктивний, комплексний тощо $^{59}$. Наявність численної кількості сформованих нині у правознавстві

\footnotetext{
${ }^{59}$ Качур В.О. Наукові підходи до розуміння поняття «2правова культура» у правознавстві. Науковий вісник НУБіП України. Серія Право. 2015. Вип. 232. С. 12-19; Когут І.А. Сучасні підходи до вивчення
} 
підходів до розуміння категорії «правова культура», засвідчує нагальну потребу в покращенні науково-методологічної роботи в цьому напрямі.

Щодо розуміння родового поняття «культура», то варто констатувати, що, незважаючи на давню історію застосування, воно нині також залишається складним і неоднозначним. Це зумовлюється тим, що воно $є$ об'єктом і предметом вивчення безлічі наук, серед яких філософія, археологія, етнографія, історія, соціологія, політологія, право, економіка та ін. Кожна з цих наук створює певне уявлення про культуру.

Крім того, не залишилися осторонь проблем культури міжнародні організації та вітчизняний нормотворець. Так, на Всесвітній конференції 3 політики в галузі культури, що була проведена під егідою ЮНЕСКО в Мексиці 26 липня - 2 серпня 1982 р., була прийнята Декларація Мехіко 3 політики в галузі культури, яка визначила останню як «сукупність яскраво виражених рис, духовних і матеріальних, інтелектуальних і емоційних, які характеризують суспільство або соціальну групу», що «охоплює, крім мистецтва й літератури, спосіб життя, основні права людини, системи цінностей, традиції та віри» ${ }^{60}$. Щодо вітчизняного законотворця, то він у п. 6 ч. 1 ст. 1 Закону України від 14.12.2010 р. № 2778-VI «Про культуру» дав іiі легальне визначення, але звузив обсяг цього явища лише до культурної спадщини та культурних цінностей (Преамбула) ${ }^{61}$.

Проведений нами аналіз феномена культури дав змогу виокремити такі іiі ознаки: 1) культура існує лише в людському середовищі; 2) з'єднувальною ланкою між людиною та навколишнім світом виступає свідомість, яка виконує функції відображення та породження навколишнього світу, який відкальковується у формах та категоріях культури; 3) людина і культура пов'язані між собою не безпосередньо, а через діяльність; 4) культура покликана організовувати людську життедіяльність; 5) культурна організація людської життєдіяльності припускає наявність порівняно несуперечливих, структурованих елементів, які є утворюють функціональну цілісність та обмежені просторово-тимчасовими межами; 6) культура визначає соціальну орієнтацію та життєву позицію людини; 7) фундамент культури становлять цінності ${ }^{62}$.

правової культури: теоретичний аспект. Вісник Львівського університету. Серія соціологічна. 2015. Випуск 9. С. 94-102; Макаренко Л. Методологічні засади пізнання сутності правової культури. Підприємництво, господарство і право». 2018. № 9. С. 181-185; Макаренко Л.О. Основні підходи у дослідженні правової культури в сучасній юридичній науці. Правова держсава. 2017. Вип. 28. С. 136-145.

${ }^{60}$ Декларація Мехіко щодо політики у сфері культури. URL: http://zakon.rada.gov.ua/laws/ show/995_730]

61 Про культуру : Закон України від 14.12.2010 р. № 2778-VI. URL: http://zakon0.rada.gov.ua/laws/ show/2778-17

${ }^{62}$ Качур В.О. До визначення поняття «правова культура» у правознавстві. Право. Людина. Довкілля: науково-практичний журнал. 2019. № 10(1). C. 17-18. DOI: http://dx.doi.org/10.31548/law2019.01.002 
Це дало нам підстави визначити культуру як специфічний спосіб організації та розвитку людської життєдіяльності в конкретних історичних умовах, що визначає соціальну орієнтацію та життєву позицію учасників суспільного життя і проявляється в цінностях.

Одним із різновидів загальної культури $є$ правова культура, яка характеризується певною автономністю щодо інших різновидів культури (матеріальної, економічної, політичної та ін.). Будучи синтезом права та культури, правова культура не має однозначного підходу до розуміння іiі сутності. Аналіз останніх праць, присвячених дослідженню сучасних підходів до розуміння правової культури, засвідчує розширення переліку методологічних підходів до дослідження цього явища та позитивні тенденції в цьому напрямі ${ }^{63}$. Але не всі вони завершуються визначенням правової культури.

Оскільки правова культура є різновидом загальної культури та уособлює синтез права та культури, пропонуємо визначати правову культуру як специфічний спосіб організації та розвитку правової життедіяльності учасників суспільного життя в конкретних історичних умовах, що визначає правову орієнтацію та правову позицію суб'єкта і проявляється у правових цінностях ${ }^{64}$.

Найповніше з'ясувати місце цінностей у теорії правової культури нам дасть змогу ії структура, у процесі дослідження якої також відчувається гострий дефіцит наукових розвідок. Водночас хочемо констатувати, що окремі наукові розвідки, присвячені єдиній теорії розуміння та аналізу структури правової культури, мають місце ${ }^{65}$. Тому пропонуємо показати іiі структуру через структуру родового поняття «культура».

Як уже зазначалося, культура покликана організовувати життєдіяльність людини, а організація будь-яких процесів базується на засадах як тектології, так і на загальній теорії систем. Крім того, в основу нового уявлення про систему закладено також i певний процес (процес функціонування, процес розвитку або єдність цих процесів), який також задає цілісність розглядуваного об'єкта ${ }^{66}$. Оскільки життєдіяльність можна визначити як діяльнісні процеси, через які відбувається тотальне переживання людиною свого буття, можна сміливо вважати, що культура

\footnotetext{
63 Макаренко Л.О. До питання про інтерпретацію поняття «правова культура». Правова держава. 2018. Вип. 29. С. 80-87.

${ }^{64}$ Качур В.О. До визначення поняття «правова культура»у у правознавстві. Право. Людина. Довкілля: науково-практичний журнал. 2019. № 10(1). C. 17-18. DOI: http://dx.doi.org/10.31548/law2019.01.002

65 Макеєва О.М., Журавльова В.Т. Структура правової культури. Url: http://er.nau.edu.ua:8080/ handle/NAU/26900; Целуйко М.В. Структура правової культури у вітчизняній юридичній літературі. Науковий вісник Чернівецького університету. Правознавство. 2010. Вип. 538. С. 5-10.

${ }^{66}$ Программа разработки методики проектирования. концепция системного проектирования. Москва, 2007. C. 60.
} 
характеризується усіма властивостями, що притаманні їй як системі. Це дає підстави виокремити головні частини ії структури.

Оскільки культура $\epsilon$ суспільно-історичним явищем, у формах та

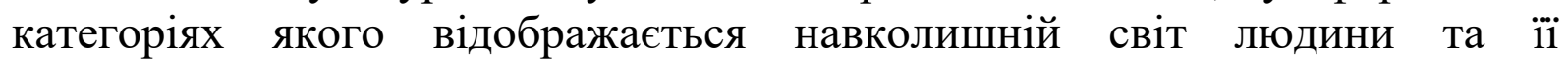
життєдіяльність, вона як явище може існувати винятково в людському середовищі. Її центральним елементом буде саме людина. Щодо людської життєдіяльності (чи то правової, чи будь-якої іншої), то вона проявляється комплексно з таких сторін: об'єктивної, суб'єктивної та нормативної.

Взаємодія людини 3 навколишнім світом найповніше проявляється в процесі людської життєдіяльності, яка є об'єктивною стороною культури. Вона не лише забезпечує пристосування людини до умов життя, а й активізує ii відповідно до своїх потреб. Головними діяльнісними процесами, які становлять основу людського способу життя, $\epsilon$ життєзабезпечення (накопичення ресурсів), життєустрій (забезпечення комфорту та благополуччя) та життєреалізація (рух до великої мрії) ${ }^{67}$.

Діяльність зумовлюється і напряму залежить від свідомості, яка $\epsilon$ з'єднувальною ланкою між людиною та навколишнім світом. Будучи цілісним, внутрішньо диференційованим і структурно оформленим психологічним процесом пізнання та відображення людиною навколишнього світу та самої себе, свідомість визначає життєву позицію суб'єкта, яка має неабияке значення для розуміння феномена культури. Прояв життєвої позиції визначає світогляд та досвід людини. Таким чином, життєва позиція, будучи суб'єктивною частиною культури, є стійкою, внутрішньо усвідомленою готовністю людини до певних дій, що грунтується на іiі світогляді і життєвому досвіді та відображає їі ставлення до інших людей, їх утворень та суспільства загалом.

Серед системних понять виділяють функціональне середовище системи - характерну для системи сукупність законів, алгоритмів та параметрів, за якими здійснюється взаємодія (обмін) елементів системи і функціонування (розвиток) системи загалом ${ }^{68}$. Оскільки культура є соціальним об’єктом, іiі функціональне середовище (нормативну частину) становитимуть соціальні регулятори, які утворюють основу соціального порядку, що пов'язує членів суспільства, регулює їх взаємодію і визначає способи ставлення до об'єктів та поводження з ними.

Кожна із цих сторін - об'єктивна (діяльність), суб'єктивна (життєва позиція) та нормативна (соціальні регулятори) - утворюють окремі частини культури як системного явища. Своєю чергою кожна 3 них $\epsilon$

\footnotetext{
${ }^{67}$ Швалб Ю.М. Просторово-психологічна організація середовища буття і життєдіяльності. Актуальні проблеми психології. 2015. Т. 7. Вип. 40. С. 199-200.

${ }^{68}$ Хомяков П.М. Системный анализ. Экспресс-курс лекций. Москва, 2008. С. 22.
} 
складним об’єктом, що включає низку компонентів, внутрішньо організованих та структурованих.

Правова культура, будучи різновидом культури, також є системним явищем. Використовуючи принцип ізоморфізму ${ }^{6}$, у структурі правової культури ми виокремили три частини - об'єктивну (правова діяльність), суб’єктивну (правова позиція) та нормативну (правові регулятори) ${ }^{70}$.

У структурі правової культури застосування поняття «цінність» $\epsilon$ ключовим. Ми застосовуємо його, коли говоримо про людину, яка є центральним елементом правової культури. Головне завдання людини усвідомлювати свою цінність протягом усього життя, особливо у процесі життєдіяльності. Це означає iї здатність збудувати власну ієрархію цінностей, які визначатимуть не лише іiі правову культуру, а й культуру загалом.

У XXI ст. світова спільнота визнала людину найвищою цінністю. Це знайшло відображення у філософській теорії людиноцентризму. На думку В.Г. Кременя, поняття людиноцентризму сповнене глибокого філософського змісту, а іiі тілесність, обдарованість, духовність, освіченість, моральність, егоїзм, розумність, цілеспрямованість є фрагментами змінюваної картини буття людини, що розкривають іiі нові аспекти i не вичерпують нескінченного змісту ${ }^{71}$.

Головні завдання концепції людиноцентризму, на думку Р.С. Мельника, полягають в тому, щоб забезпечити соціально-правову трансформацію суспільства і держави, результатом якої стане «перетворення» приватних осіб на громадян, вільних особистостей, звільнити приватних осіб від думки про те, що вони лише «гвинтик» державного механізму, сприяти виробленню, перш за все, норм адміністративного права, які зобов'язували б державу служити виключно інтересам приватних осіб, стати сполучною ланкою між принципом верховенства права і його реалізацією на практиці, втілити у життя ідею, сформульовану Ф.Д. Рузвельтом, що «обов’язок держави перед громадянином - це обов’язок слуги перед господарем» ${ }^{72}$.

Людиноцентризм, який нині став важливим напрямом гуманістично спрямованої політики держави в процесі державотворення і правотворення, позитивно впливає на свідомість та формування індивідуальних якостей

\footnotetext{
69 Качур В. Перспективи застосування принципу ізоморфізму при дослідженні правової культури. Проблеми юридичної науки очима молодих науковиів : збірник наук. праць ХІІІ Всеукр. наук.-практ. конф., м. Київ, 5 грудн. 2019 р. Київ, 2019. С. 217-219.

${ }^{70}$ Качур В.О. До питання про структуру правової культури. Право. Людина. Довкілля: науковопрактичний журнал. 2019. № 10(2). С. 10.

${ }^{71}$ Кремень В.Г. Філософія людиноцентризму в стратегіях освітнього простору. Київ : Педагогічна думка, 2008. С. 8

72 Мельник Р.С. Новели сучасної концепції українського адміністративного права. Lex Portus. 2017. № 5. C. 8 .
} 
людини. Не останнє місце в дослідженні людиноцентризму займає аксіологічний підхід. Конституція України визнає людину найвищою соціальною цінністю, поряд з іншими різновидами цінностей, що склалися в суспільстві, державі та праві. Ціннісний (аксіологічний) підхід дає змогу охарактеризувати права та свободи людини як одну з фундаментальних цінностей у державі та суспільстві ${ }^{73}$.

Ми можемо зустріти його, коли йтиметься про будь-яку зі сторін правової культури - об'єктивну, суб'єктивну чи нормативну. Ми згадуватимемо про цінності, коли будемо розкривати особливості тієї чи іншої юридичної діяльності, зіставляючи мету та досягнуті результати (об'єктивна сторона), коли постане необхідність з'ясувати правову позицію особи з їі ціннісно-правовими установками та ціннісно-правовими орієнтаціями $^{74}$ (суб'єктивна сторона), коли мова йтиме про правові регулятори - норми та принципи права, догму права та правову доктрину (нормативна частина).

\section{ВИСНОВКИ}

Проведене дослідження показало плюралізм наукового розуміння поняття «цінність», його складність та неоднозначність, що зумовлюється його міждисциплінарною природою. Виокремлення властивостей цінностей дало підстави визначати їх як явища об'єктивного світу (матеріальні та духовні), що мають значення для суб'єкта під час здійснення ним життєвого вибору.

Людська історія засвідчує, що глобалізаційні виклики змушують людство переосмислювати свої цінності, а також роль держави і права в їх подоланні. Таке переосмислення ми спостерігаємо як на буденному, так i на науковому рівні. Але незалежно від рівня, на якому відбувається такий процес, з'єднувальною ланкою між ними буде правова культура, що відіграє важливу роль не лише у формуванні громадянського суспільства, а й у житті окремої людини та в історії людства загалом.

Будучи різновидом загальної культури, правова культура уособлює собою синтез таких понять, як «право» та «культура», і $\epsilon$ специфічним способом організації та розвитку правової життєдіяльності учасників суспільного життя в конкретних історичних умовах, що визначає правову орієнтацію та правову позицію суб'єкта і проявляється в правових цінностях.

\footnotetext{
73 Тарахонич Т.І. Людиноцентризм у праві та у правовому регулюванні: реалії сьогодення. Альманах права. 2017. Вип. 8. С. 281-284.

${ }^{74}$ Качур В.О. Правова позиція як суб'єктивна частина правової культури: до постановки питання. Право. Людина. Довкілля: науково-практичний журнал. 2019. № 10(4). С. 6-12.
} 
Найповніше з'ясувати місце цінностей у теорії правової культури дає змогу іiі структура, яка охоплює три частини - об'єктивну (правова діяльність), суб'єктивну (правова позиція) та нормативну (правові регулятори). Але центральним елементом правової культури як системи $\epsilon$ людина.

У теорії правової культури поняття «цінність» вживається, коли йдеться про цінність правової культури (властивість правової культури, що дає змогу розкрити іï сутність як суспільно-історичного явища, що забезпечує ефективність правового регулювання), цінності правової культури (явища об'єктивного світу, що дають змогу розкрити цінність правової культури) та правові цінності (фундамент правової культури).

\section{АНОТАЦІЯ}

У статті з'ясовано місце поняття «цінність» у теорії правової культури. За результатами дослідження встановлено, що в наукових дослідженнях відсутній однозначний підхід до природи та сутності категорії «цінність». Виокремлено властивості цінності і сформульовано іiі поняття. У процесі характеристики правової культури необхідно враховувати полісемантичність поняття, поєднання в категорії «правової культури» культурологічного («культура») та юридичного явища («право») і наявність різних методологічних підходів до їі дослідження. У структурі правової культури виокремлено три частини: об'єктивна (правова діяльність), суб'єктивна (правова позиція) та нормативна (правові регулятори). Розкрито місце поняття «цінність» у кожній із них. Підкреслено, що в теорії правової культури поняття «цінність» вживається, коли йдеться про цінність правової культури (властивість правової культури, що дає змогу розкрити іiі сутність як суспільно-історичного явища, що забезпечує ефективність правового регулювання), цінності правової культури (явища об'єктивного світу, що дають змогу розкрити цінність правової культури) та правові цінності (фундамент правової культури).

\section{ЛIТЕРАТУРА}

1. Арон Р. Етапи розвитку соціологічної думки / пер. 3 фр. Г. Філіпчука. Київ : Юніверс, 2004. 688 с.

2. Бабенко Ю. Теоретичні аспекти дослідження цінностей. Вісник Національної академії керівних кадрів культури і мистещтв. 2013. № 3. C. 88-93. URL: http://nbuv.gov.ua/UJRN/vdakkkm_2013_3_23.

3. Бех І.Д. Виховання особистості: сходження до духовності. Київ : Либідь, 2006. 272 с. 
4. Блікхар М.П. Духовні цінності студентської молоді в сучасному українському суспільстві : дис. канд. соціолог. наук : 22.00 .04 / Львівський національний університет імені Івана Франка. Львів, 2018. 271 с.

5. Василенко В.А. Ценность и ценностные отношения. Проблема иенности в философии. Москва-Ленинград : Издательство «Наука», 1966. $262 \mathrm{c}$.

6. Виндельбанд В. От Канта до Ницше: История новой философии в ее связи с общей культурой и отдельными науками / пер. с нем. А.И. Введенского. Москва : КАНОН-пресс: Кучково поле, 1998. $640+512$ с.

7. Гаврилишин Б. До ефективних суспільств: Дороговкази в майбутнє: доповідь Римському Клубові. Вид. 3-те, допов. Київ : Унів. вид-во «ПУЛЬСАРИ», 2009. 248 с.

8. Гартман Н. Эстетика. Київ : Ника-Центр, 2004. 640 с.

9. Гидденс Э. Ускользающий мир: как глобализация изменяет нашу жизнь / пер. с англ. М.Л. Коробочкина. Москва : Весь мир, 2004. С. 120.

10. Глубіш Л. Система цінностей як базис формування економічних інтересів стейкхолдерів як вектор економічних ефектів від їх реалізації. Економіка $і$ суспільство. 2017. Випуск № 9. С. 171-175. URL: http://www.economyandsociety.in.ua/journal/9_ukr/29.pdf

11. Горбатюк С.С. Теорія цінностей як методологічна основа аксіології соціогуманітарної безпеки. Вісник Наџіональної академії державного управління при Президентові Украӥни. Серія: Державне управління. 2016. № 4. C. 20-30.

12. Гуманізація навчально-виховного процесу. Спецвипуск 4. Ч. 2. Слов'янськ, 2010. 355 с.

13. Деклараиіл Мехіко щчодо політики у сфері культури. URL: http://zakon.rada.gov.ua/laws/show/995_730

14. Діденко О. Виклики сучасності, тенденції та проблеми професійного виховання майбутніх офіцерів-прикордонників. Збірник наукових прачь Начіональної академії Державної прикордонної служби України. Серія : Педагогічні науки. 2016. № 1. C. 70-81. URL: http://nbuv.gov.ua/UJRN/znpnadpcpn_2016_1_8

15. Дюркгейм Э. Ценностные и «реальные» суждения. Сои. исследования. 1991. № 2. С. 106-114.

16. Жеребятнікова І.В. Цінності політичного життя у сучасному українському соціумі. Вісник Харківського національного університету імені В.Н. Каразіна. Серія: Питання політології 2013. № 1060, вип. 23. C. 52-59. URL: http://nbuv.gov.ua/UJRN/VKhIPP_2013_1060_23_12

17. Про культуру : Закон України від 14.12.2010 р. № 2778-VI. URL: http://zakon0.rada.gov.ua/laws/show/2778-17 
18. История социологии в Западной Европе и США. Москва : Наука, 1993. $424 \mathrm{c}$.

19. Історія вчень про право i державу: Хрестоматія для юрид. вузів $\mathrm{i}$ фак. / уклад., заг. ред. - проф.., д-р іст. наук Г. Демиденко. 2-е вид., доп. і змін. Харків : Дух і літера, 2000. 256 с.

20. Кавалеров А.А. Цінність у соціокультурній трансформації : монографія. Одеса : Астропринт, 2001. 224 с.

21. Каган М.С. Философская теория ценностей. Лекции. СанктПетербург : ТОО ТК Петрополис, 1997. 205 с.

22. Калюжна Т.Г. Педагогічна аксіологія в умовах модернізації професійно-педагогічної освіти : монографія / за наук. ред. О.В. Уваркіної. Київ : Вид-во НПУ імені М.П. Драгоманова, 2012. 128 с.

23. Карась А.Г. Роль релігійних цінностей у процесі формування права. Часопис Київського університету права. 2010. № 4. С. 60. URL: http://dspace.nbuv.gov.ua/bitstream/handle/123456789/23643/13-Karas.pdf

24. Карташкин В.А. Универсализация прав человека и традиционные ценности человечества. Современное право. 2012. № 8. С. 3-9.

25. Качур В. Перспективи застосування принципу ізоморфізму при дослідженні правової культури. Проблеми юридичної науки очима молодих науковців : збірник наук. пр. XIII Всеукр. наук.-практ. конф., м. Київ, 5 грудн. 2019 р. Київ, 2019. С. 217-219.

26. Качур В.О. До визначення поняття «правова культура» у правознавстві. Право. Людина. Довкілля: науково-практичний журнал. 2019. № 10(1). C. 12-19. DOI: http://dx.doi.org/10.31548/law2019.01.002

27. Качур В.О. Категорія «цінність» у теорії правової культури: до визначення поняття. Право. Людина. Довкілля: науково-практичний журнал.2020. 11(1). С. 10. DOI: http://dx.doi.org/10.31548/law2020.01.001

28. Качур В.О. Наукові підходи до розуміння поняття «правова культура» у правознавстві. Науковий вісник НУБіП Украӥни. Серія Право. 2015. Вип. 232. С. 12-19.

29. Качур В.О. Правова позиція як суб'єктивна частина правової культури: до постановки питання. Право. Людина. Довкілля: науковопрактичний журнал. 2019. № 10(4). С. 6-12. DOI: http://dx.doi.org/ 10.31548/law2019.04.001

30. Когут І.А. Сучасні підходи до вивчення правової культури: теоретичний аспект. Вісник Львівського університету. Серія соціологічна. 2015. Випуск 9. С. 94-102.

31. Кремень В.Г. Філософія людиноцентризму в стратегіях освітнього простору. Київ : Педагогічна думка, 2008. 424 с. 
32. Культурологія: теорія та історія культури : Навчальний посібник / За ред. I.I. Тюрменко, О.Д. Горбула. Київ : Центр навчальної літератури, 2004. 368 c. URL: http://www.info-library.com.ua/books-text-1114.html

33. Левківська К.В. Ціннісні засади діяльності освітніх закладів: навч.метод. посібник. Житомир : Вид-во ЖДУ, 2017. 136 с.

34. Макаренко Л.О. Методологічні засади пізнання сутності правової культури. Підприємництво, господарство і право». 2018. № 9. С. 181-185.

35. Макаренко Л.О. Основні підходи у дослідженні правової культури в сучасній юридичній науці. Правова держава. 2017. Вип. 28. С. 136-145.

36. Макаренко Л.О. До питання про інтерпретацію поняття «правова культура». Правова держава. 2018. Вип. 29. С. 80-87.

37. Макеєва О.М., Журавльова В.Т. Структура правової культури. «Юридична наука Украӥни: історія, сучасність, майбутнє» : Міжнародна науково-практична конференція, 5-6 грудня 2014 р.: тези доп. Донецьк, 2014. C. 8-11. URL: http://er.nau.edu.ua:8080/handle/NAU/26900;

38. Мартышин О.В. Проблемы ценностей в теории государства и права. Государство и право. 2004. № 10. С. 5-14.

39. Мельник Р.С. Новели сучасної концепції українського адміністративного права. Lex Portus. 2017. № 5. С. 5-16.

40. Мо-Цзы. Этические воззрения. Антология мировой философии: В 4-х т. т. 1. Ч. 1. Москва : Мысль, 1969. 576 с.

41. Нагой Ф.Н. Теории ценностей и проблема целостности мировоззрения личности Вестник Пермского университета. Выпуск 1. Философия. Психология. Сочиология. 2017. С. 20-28. DOI: 10.17702/20787898/2017-1-20-28

42. Невмержицька О.М. Релігійно-філософська естетична аксіологія : дис. ... канд. філософ. наук : 09.00.11. Київ, 2019. 210 с.

43. Неновски Н. Право и ценности: пер. с болг. Москва : Прогресс, 1987. $248 \mathrm{c}$.

44. Пачковський Ю.Ф. Максименко А.О. Споживча поведінка українських домогосподарств : монографія. Львів : ЛНУ ім. І. Франка, 2014. 294 c.

45. Петінова О.Б. Проблема цінності в філософії. Культура народов Причерноморья. 2002. № 36. С. 185-188.

46. Программа разработки методики проектирования. Концепция системного проектирования. Москва, 2007, с. 60.

47. Радбрух Г. Философия права: пер. с нем. Москва : Междунар. отношения, 2004. $238 \mathrm{c}$. 
48. Радченко О.В. Цінність в системі державного управління: категоріальний аспект. Державне будівниитво. 2008. № 2. URL: http://nbuv.gov.ua/UJRN/DeBu_2008_2_6

49. Радченко О.В. Генезис розуміння державно-управлінських цінностей у політичній філософії від нового часу до кінця ХІХ ст. Теорія $i$ практика державного управління. 2009. Вип. 1(24). С. 66-72.

50. Рассел Б. История западной философии и ее связи с политическими и социальными условиями от Античности до наших дней: В трёх книгах. Издание 6-е, стереотипное. Москва : Академический проспект; Деловая книга, 2008. 839 c. URL: http://psylib.org.ua/books/rassb01/index.htm

51. Руденко А.M. Социовитальные ценности смысложизненной интенциональности екзистенции человека. Экономические $u$ гуманитарные исследования регионов. 2012. № 3. С. 165-172.

52. Ручка А. Цінності та ціннісна зміна у сучасному суспільстві Прикладна культурологія $і$ культурні практики Культурологічна думка, Щорічник наукових пращь. Київ : Інститут культурології Національної академії мистецтв України, 2013. № 6. С. 172-179.

53. Сидорова Е.В. Миф о правовых ценностях История государства и права. 2012. № 11. С. 24-26.

54. Смельзер Н. Соціологія. Москва : Феникс, 1994. 688 с.

55. Стасевич В.П. Цінність як категорія i принцип осмислення культури. URL: http://ea.donntu.org:8080/jspui/bitstream/123456789/1544/ 17/stasevich.htm

56. Столович Л.Н. Философия, Эстетика, Смех. Санкт-Петербург, Тарту, 1999. 384 с.

57. Тарахонич T.I. Людиноцентризм у праві та у правовому регулюванні: реалії сьогодення. Альманах права. 2017. Вип. 8. С. 281-284.

58. Філософський енциклопедичний словник / редкол.: В.І. Шинкарук / Національна академія наук, Інститут філософії імені Г.С. Сковороди. Київ : Абріс, 2002. $742 \mathrm{c}$.

59. Хомяков П.М. Системный анализ. Экспресс-курс лекций. Москва, 2008. 216 c.

60. Целуйко М.В. Структура правової культури у вітчизняній юридичній літературі. Науковий вісник Чернівеиького університету. Правознавство. 2010. Вип. 538. С. 5-10.

61. Шайгородський Ю. Ж. Ціннісний конструкт міжкультурної комунікації. Украӥнський соиіум. 2002. № 1. С. 41-48.

62. Швалб Ю.М. Просторово-психологічна організація середовища буття і життєдіяльності. Актуальні проблеми психології. 2015. Т. 7. Вип. 40. C. 199-200. 
63. Шелер М. Избранные произведения : сборник статей. Москва, 1994. $490 \mathrm{c}$.

64. Этциони А. Что придет на смену консьюмеризма? Свободная мысль XXI. 2009. № 8. С. 53-62.

65. Ярошко О.3. Цінність як наукова категорія. Свропейські культурноісторичні иінності: ретроспектива і перспектива: збірник наук. пр. / за заг. ред. О.В. Зернецької. Державна установа «Інститут всесвітньої історії НАН України». Київ : ДУ «Інститут всесвітньої історії НАН України». 2018. C. 47-54.

\section{Information about authors:} Kachur V. O.,

$\mathrm{PhD}$., Associate Professor, Head of the Department of State and Law National University of Life and Environmental Sciences of Ukraine 17, Vasylkivska Str., Kyiv, Ukraine Protosavitska L. S., $\mathrm{PhD}$., Associate Professor of the Department of State and Law National University of Life and Environmental Sciences of Ukraine 17, Vasylkivska Str., Kyiv, Ukraine 